\title{
Estrogen and Progestin Receptors Appear in Transplanted Fetal Hypothalamus-preoptic Area Independently of the Steroid Environment ${ }^{1}$
}

\author{
CHARLES M. PADEN, ${ }^{*, 2}$ JOHN L. GERLACH,‡ AND BRUCE S. McEWEN‡ \\ * Department of Biology, Montana State University, Bozeman, Montana 59717 and $\neq$ Laboratory of Neuroendocrinology, The Rockefeller \\ University, New York, New York 10021
}

\begin{abstract}
Sexual maturation and differentiation of the rat brain are believed to result from the interaction of gonadal steroids with specific neural receptors during late fetal and early postnatal life. A variety of evidence indicates that the first appearance of estrogen receptors in the hypothalamuspreoptic area (HPOA) during the perinatal period is a crucial evident underlying these processes. However, it is unknown to what extent the ontogeny of estrogen receptors is itself influenced by gonadal steroids present in the fetal environment. In order to address this question, estrogen receptors were assayed in HPOA 8 weeks after transplantation of the tissue from embryonic day 15 to 18 fetuses to either the choroidal pia overlying the superior colliculus or to the anterior chamber of the eye of adult female hosts. Host animals were either intact or ovariectomized and adrenalectomized, with or without estrogen replacement.

The saturable binding of estradiol to cytosol of HPOA transplants exhibited the steroid specificity and high affinity characteristic of authentic estrogen receptors. No differences in the level of cytosol estrogen receptors in transplanted HPOA grown in the presence or absence of gonadal steroids were found. Receptor concentrations were also similar in HPOA taken from male or female fetuses. Autoradiography with $\left[{ }^{3} \mathrm{H}\right]$ estradiol revealed clusters of estrophilic cells in the transplants similar to those of the adult host hypothalamus, again regardless of whether the transplant developed in the presence of gonadal steroids. Estrogen receptors from both groups were also found to be biochemically functional as indlcated by the ability of acute estrogen treatment to induce progestin receptors in the transplants.

These data indicate that estrogen receptors develop in the HPOA of both sexes independently of the gonadal steroid environment. This finding suggests that the capacity for responding to gonadal steroids is inherent in the developing HPOA, consistent with the hypothesis that fetal testicular secretions activate a pre-existing neural mechanism to induce sexual differentiation of the brain.
\end{abstract}

The sexual differentiation of the rodent brain depends upon its ability to respond to estrogens during the late fetal and early postnatal period. Although androgen secretion by the developing testes results in both defeminization (decreased propensity for fcmalc scxual bchavior and induction of acyclic gonadotropin secre-

Received September 10, 1984; Revised February 11, 1985;

Accepted February 13, 1985 tion) and masculinization (increased propensity for male sexual and aggressive behaviors) of the male brain (Beach, 1975), several lines of cvidence suggest that androgens must first be converted to estrogens in order for complete sexual differentiation to occur. Enzymatie conversion of androgens to estrogens (aromatization) by fetal and neonatal rat brain has been demonstrated both in vitro (Reddy et al., 1974; Weisz et al., 1982) and in vivo (Weisz and Gibbs, 1974; Lieberburg and McEwen, 1975). Indeed, the highest levels of neural aromatase activity at any period of life are found in the preoptic area at embryonic day 19 (E19) (George and Ojeda, 1982; Weisz et al., 1982). Implants of either estrogens or aromatizable androgens directly into the neonatal brain are capable of inducing sexual differentiation (Christensen and Gorski, 1978), whereas androgens such as dihydrotestosterone, which cannot be aromatized, are much less effective (Plapinger and McEwen, 1978). Finally, treatment with either inhibitors of aromatization (Booth, 1977; McEwen et al., 1977; Vreeburg et al., 1977) or an estrogen receptor antagonist (McEwen et al., 1979) blocks the defeminizing effects of androgens in newborn rats. Thus, occupation of neural estrogen receptors by aromatized androgens is thought to play an essential role in brain sexual differentiation.

The ontogeny of neural estrogen receptors is also consistent with their involvement in sexual differentiation. Estrogen receptors are first detected in the fetal hypothalamus-preoptic area (HPOA) and amygdala during the last week of pregnancy, between E15 (Vito and Fox, 1982) and E21 (Maclusky et al., 1979a). Although there is disagreement over the precise age of their first appearance, it is clear that the number of receptors in limbic structures increases dramatically from E21 throughout the first postnatal week (MacLusky et al., 1979a), coinciding with the critical period for defeminization (Barraclough and Gorski, 1962). Furthermore, significant numbers of receptors are found translocated into cell nuclei in limbic tissues of male rats as early as E21 (MacLusky et al., 1979a). Translocated receptor complexes are 5-fold lower in female embryos at this age, and this sex difference is consistent with the hypothesis that aromatization of circulating androgens is the principal source of estrogens occupying neural receptors in the perinatal period.

These findings indicate that knowledge of the factors which influence the first appearance of neural estrogen receptors is required for a thorough understanding of brain sexual maturation and differentiation. The present study was undertaken to determine

1 This work was supported by National Institutes of Health Grants NS17974 to C. M. P. and NS07080 to B. S. M. We wish to thank Claude Chaptal Valerie DeGroff, and Marie Wilson for expert technical assistance. Statistical analysis was performed using a one-way analysis of variance program AV1F version 2.20, part of the MSUSTAT statistical package developed by Richard ᄃ. Lund of Montana State University.

2 To whom correspondence should be addressed 


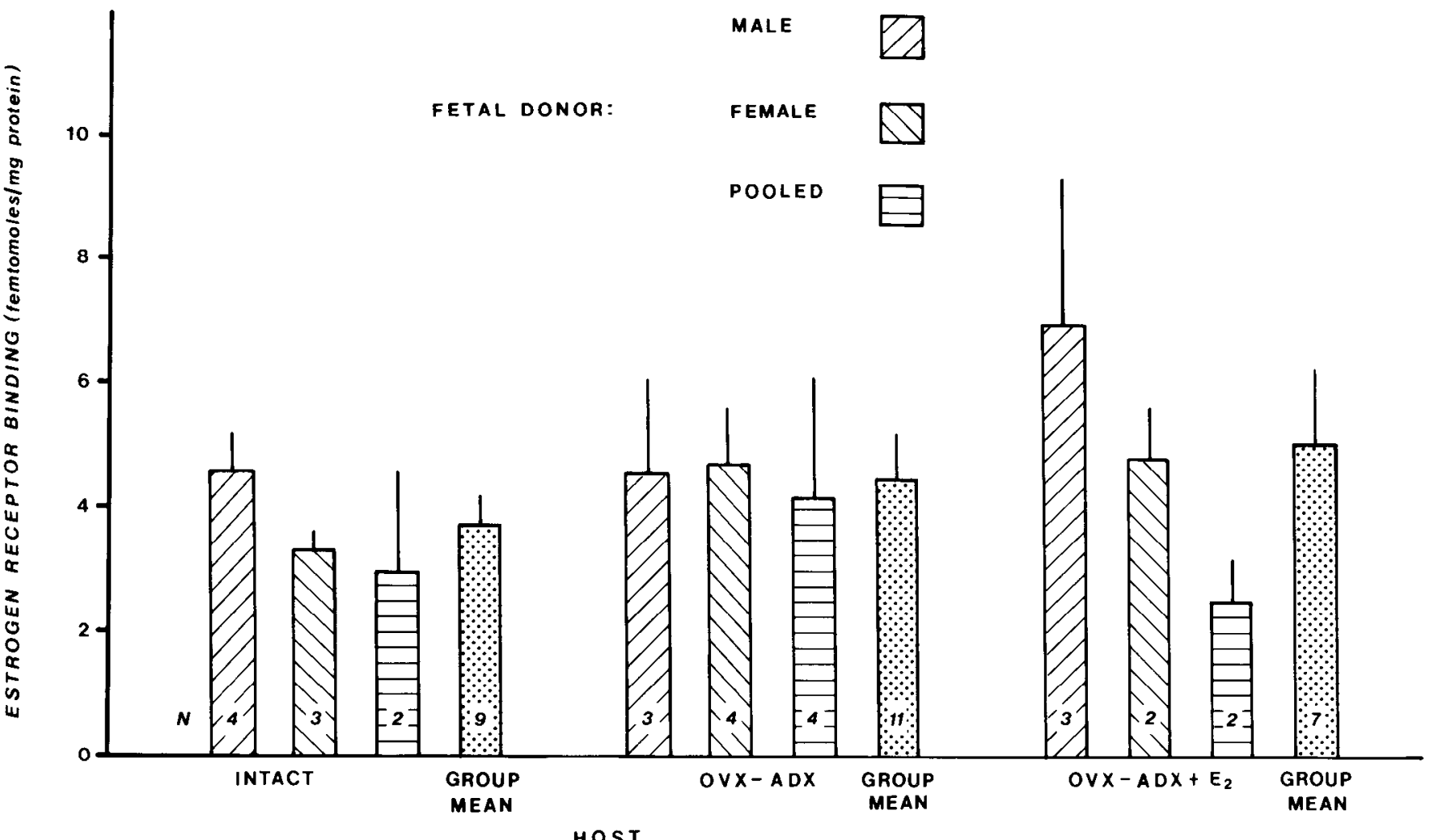

Figure 1. Cytosol estrogen receptors in E17-18 HPOA transplants grown on the choroidal pia of gonadally intact, ovariectomized-adrenalectomized (OVX$A D X)$, or ovariectomized-adrenalectomized plus estrogen replaced $\left(O V X-A D X+E_{2}\right)$ female hosts. Transplants were performed and receptor binding was determined 8 weeks later as described under "Materials and Methods." A one-factor analysis of variance revealed that receptor levels were not affected by either the endocrine status of the host $(F=0.60 ; d f=2 / 24, p=0.56)$. There was also no difference between overall levels from male versus female donors (see "Results").

TABLE ।

Cytosol estrogen receptors in E15-16 HPOA transplants

Cytosol estrogen receptor binding in E15-16 HPOA transplants grown on the choroidal pia of intact or ovariectomized-adrenalectomized (OVX-ADX) female hosts is shown. Transplants were performed and receptor binding was determined 8 weeks later as described under "Materials and Methods." There was no effect of host endocrine status on receptor levels expressed in either manner as determined by Student's $t$ test, two-tailed (femtomoles/ $\mathrm{mg}$ of protein, $t=0.96, d t=10$; temtomoles/transplant, $t=0.52, d f=10$ ).

\begin{tabular}{lccc}
\hline \multirow{2}{*}{ Host } & \multicolumn{2}{c}{ Estrogen Receptor Binding } \\
\cline { 2 - 4 } & Femtomoles/mg of protein & $N$ & Femtomoles/transplant \\
\hline Intact female & $1.30 \pm 0.27^{a}$ & 7 & $1.26 \pm 0.35$ \\
OVX-ADX female & $2.03 \pm 0.71$ & 5 & $1.60 \pm 0.55$ \\
\hline
\end{tabular}

${ }^{a}$ Values are mean \pm SEM.

whether the development of estrogen receptors in the fetal HPOA is dependent upon the presence of gonadal steroids, particularly estrogens themselves. Fetal brain is exposed to a complex variety of steroid hormones, produced by maternal as well as fetal glands (Milkovic et al., 1973; Chatelain et al., 1980; Weisz and Ward, 1980). It is therefore necessary to remove embryonic brain tissue from the fetus in order for it to mature in a controlled hormonal environment. We have shown previously that fetal rat HPOA will survive and differentiate following transplantation to a site prepared on the choroidal pia of adult hosts and that cells in the transplanted tissue develop the capacity to sequester [ $\left.{ }^{3} \mathrm{H}\right]$ estradiol (Stenevi et al., 1980). In the present study we have used the fetal transplant technique to investigate the influence of gonadal steroids on the development of specific estrogen and progestin receptors in the HPOA of the rat.
TABLE H

Comparison of cytosol estrogen receptors in E15-16 versus E17-18 HPOA transplants

Cytosol estrogen receptor binding is compared in E15-16 and E17-18 HPOA transplants grown on the choroidal pia of adult female hosts. Transplants were performed and receptor binding was determined 8 weeks later as described under "Materials and Methods." Values from all different host groups were pooled for comparison of fetal ages. Values are mean \pm SEM.

\begin{tabular}{cccc}
\hline \multirow{2}{*}{ Transplant Donor Age } & \multicolumn{3}{c}{ Estrogen Receptor Binding } \\
\cline { 2 - 4 } & Femtomoles/mg of protein & $N$ & Femtomoles/transplant \\
\hline E15-16 & $1.60 \pm 0.34^{\circ}$ & 12 & $1.40 \pm 0.30^{\circ}$ \\
E17-18 & $4.41 \pm 0.47$ & 27 & $1.61 \pm 0.20$ \\
\hline
\end{tabular}

${ }^{a}$ Mean estrogen levels are significantly lower in E15-16 transplants when expressed as femtomoles/mg of protein $(t=4.84$, df $=37, p<0.01)$.

${ }^{b}$ There is no difference between mean levels in E15-16 and E17-18 transplants, however, when expressed as femtomoles/transplant $(t=0.58$, $d f=37$, not significant).

\section{Materials and Methods}

Animals. Sprague-Dawley-derived albino $C D$ rats were purchased from Charles River Breeding Laboratories (Wilmington, MA) or bred in our colony from Charles River stock. The entire medial and periventricular HPOA was dissected from embryos of crown-rump length 15 to $24 \mathrm{~mm}(\mathrm{E} 15$ to $\mathrm{E} 18$, counting the day the vaginal plug was found as day 1) and transplanted onto the vessel-rich pia overlying the superior colliculus of adult hosts as described previously (Stenevi et al., 1976, 1980). Fetal sexes were determined in day 17 and 18 embryos by examination of the gonads under a dissecting microscope. In some cases transplants were made into the anterior chamber of the eye as described elsewhere (Olson and Malmfors, 1970). Hosts were (a) intact female rats of 160 to $250 \mathrm{gm}$ body weight at the time of transplantation, or $(b)$ ovariectomized and adrenalectomized (OVX-ADX) at least $72 \mathrm{hr}$ before transplantation, or (c) OVX-ADX and 


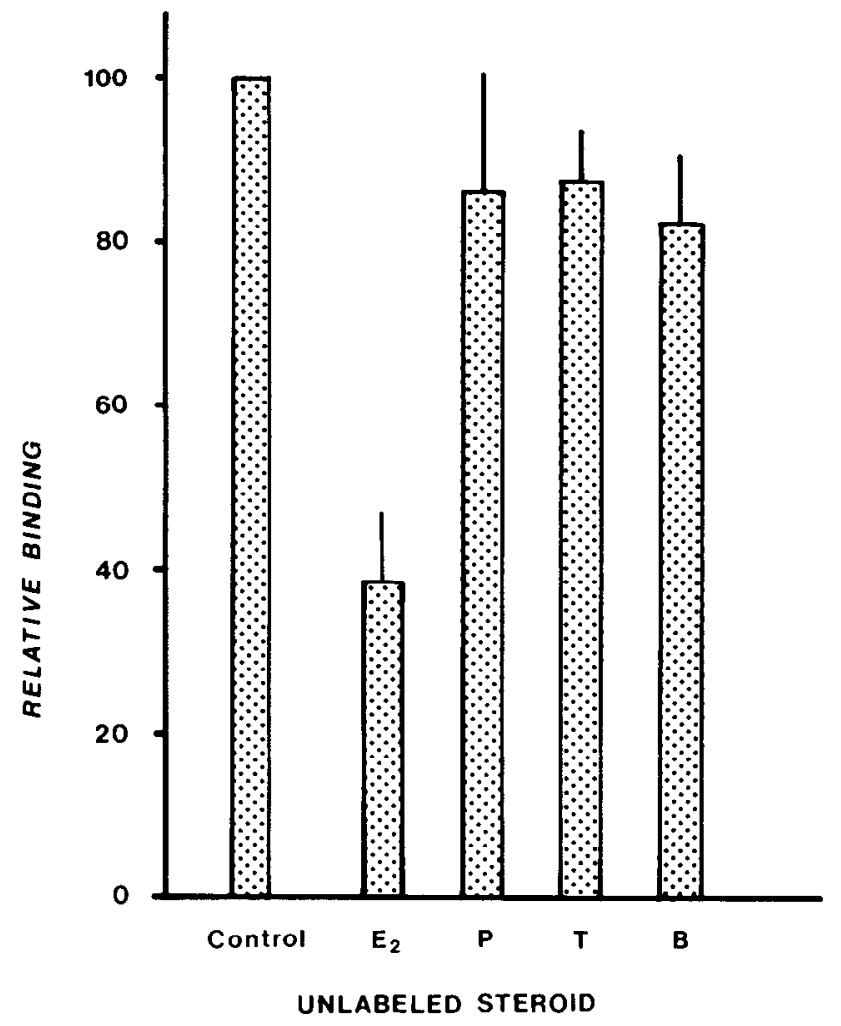

Figure 2. Steroid specificity of radiolabeled estradiol binding to cytosol receptors from E17-18 HPOA transplants. Transplants onto the choroidal pia were performed and receptor binding was determined 8 weeks later as described under "Materials and Methods." Unlabeled estradiol $\left(E_{2}\right)$, progesterone $(P)$, testosterone $(T)$, or corticosterone $(B)$ were added to the incubation medium in a 300 -fold molar excess compared to the radiolabeled estradiol. Only unlabeled estradiol was effective in reducing binding, as is characteristic of authentic estrogen receptors. Each point is the mean of two separate experiments.

implanted subcutaneously with a $1 . \mathrm{cm}$ Silastic capsule of pure estradiol. All OVX-ADX animals were implanted with a 100-mg pellet of fused 50:50 corticosterone:cholesterol at the time of adrenalectomy.

Fstrogen and progestin receptor assays. Estradiol Silastics were removed 4 weeks following transplantation, and host animals were killed by decapitation 8 weeks after transplantation. Intact animals used in steroid receptor assays were ovariectomized at least $48 \mathrm{hr}$ before death. Transplants assayed for estrogen or progestin receptors were dissected from the host brain or eye on an ice-cold glass plate. Cytosol estrogen receptors were assayed as described previously (MacLusky et al., 1979b) with minor modifications. In initial studies, two to six transplants from same-sex fetuses were pooled for each assay point using $\left[6,7^{-3} \mathrm{H}\right]$ estradiol $17 \beta(55 \mathrm{Ci} / \mathrm{mmol}$; New England Nuclear, Boston, MA) as the ligand. The availability of $\left.\left.16 \alpha-{ }^{[25}\right]\right]-3$-estradiol $17 \beta$ (initial specific activity, $1611 \mathrm{Cl} / \mathrm{mmol}$; New England Nuclear) made it possible to measure receptor levels in cytosol prepared from only one or two transplants in later experiments. The specific activity of $\left[{ }^{125} \mid\right]$ estradiol was corrected for both radiodecay and radio-induced chemical decomposition prior to each assay. Cytosol progestin receptors were measured as described previously (MacLusky and McEwen, 1980a) using the synthetic progestin $17 \alpha-\left[\right.$ methyl $\left.{ }^{3} \mathrm{H}\right] \mathrm{R} 5020$ (promegestrone; $56 \mathrm{Ci} / \mathrm{mmol}$; New England Nuclear). Estrogen-induced progestin receptors were measured in transplant cytosol from hosts given subcutaneous injections of $10 \mu \mathrm{g}$ of estradiol benzoate in sesame oil 72 and $48 \mathrm{hr}$ before sacrifice. Total cytosol protein was determined by the method of Bradford (1976).

Estradiol autoradiography. Autoradiography of $\left[{ }^{3} \mathrm{H}\right]$ estradiol concentrated in vivo by estrophilic cells in transplants and host hypothalamus was performed as described previously (Stenevi et al., 1980) in OVX-ADX hosts and intact hosts. The latter were ovariectomized at least $48 \mathrm{hr}$ before injection of $100 \mu \mathrm{Ci}$ of $\left[{ }^{3} \mathrm{H}\right]$ estradiol into the tail vein.

Materials. Steroids (testosterone, estradiol, progesterone, and corticosterone) were obtained from Steraloids (Wilton, $\mathrm{NH}$ ) and used without further purification. Medical grade Silastic tubing was obtained from Dow Corning

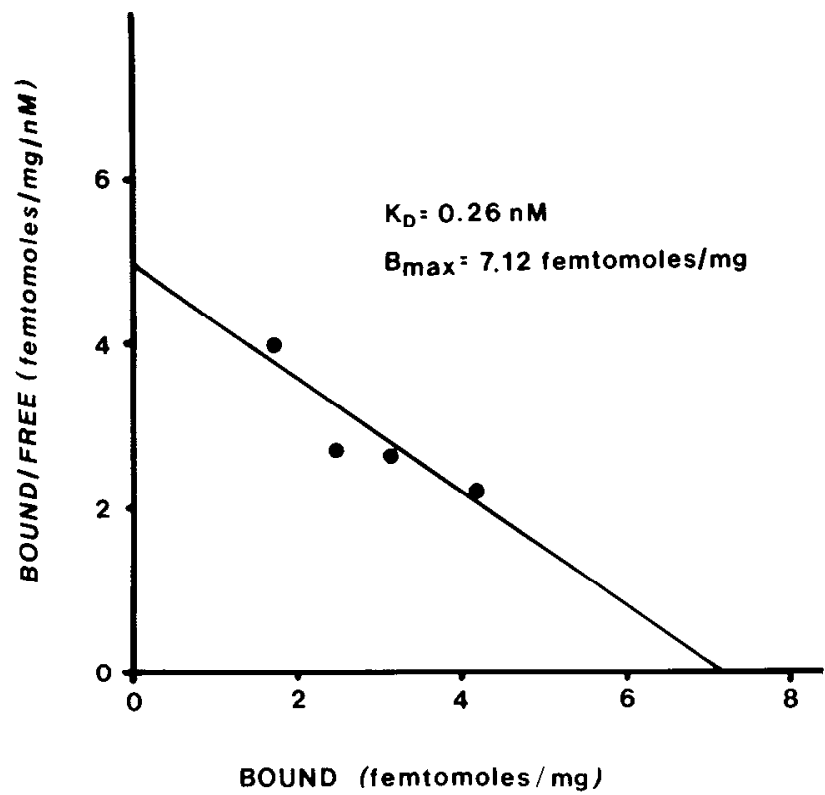

Figure 3. Equilibrium binding characteristics of cytosol estrogen receptors from E17-18 HPOA transplants. Transplants onto the choroidal pia were performed and receptor binding was determined 8 weeks later as described under "Materials and Methods." [ $\left.{ }^{125}\right]$ Estradiol concentrations were varied from 0.078 to $0.341 \mathrm{~nm}$, and the specific cytosol receptor binding (duplicate determinations) versus ligand concentration was expressed as a Scatchard plot. Linear regression analysis gave an estimated equilibrium dissociation constant $\left(K_{a}\right)$ of $0.26 \mathrm{nM}$, comparable to that of estrogen receptors in the adult HPOA.

Corp. (Midiand, MI). All other materials were reagent grade, and distilleddeionized water was used throughout.

\section{Results}

\section{Levels of cytosol estrogen receptors in transplanted HPOA}

Effect of host endocrine status and fetal donor sex. Figure 1 shows the levels of saturable estrogen receptor binding in cytosol of 8-week HPOA transplants taken from E17-18 fetuses. Adult host animals were either intact females, OVX-ADX, or OVX ADX implanted with estradiol Silastics during the first 4 weeks following transplantation. Estrogen receptor levels in transplant cytosol were not affected by these manipulations of the endocrine status of the host. In some experiments cytosol from transplants of same-sex donors was pooled prior to assay, whereas in others the limited amount of tissue available necessitated mixing cytosol from different sexes. Measurable cytosol estrogen receptors were found in all cases. Although the number of same-sex determinations within each group is insufficient for statistical analysis of treatment by donor sex interactions, no obvious differences between the sexes within the OVX-ADX and intact host groups are apparent. The seemingly greater male level in the OVX-ADX $+E_{2}$ group is due to a single high value, resulting in a large SEM for this group. Average levels of cytosol estrogen receptors are not different in transplants from male versus female donors when values are pooled across host treatment groups (males, $5.29 \pm 0.87 \mathrm{fmol} / \mathrm{mg}$ of protein, $n=10$; females, $4.27 \pm 0.48, n=9$ : Student's $t=1.17, d f=17$, not significant).

Effect of fetal donor age and site of transplantation. In order to determine whether the development of HPOA estrogen receptors might be dependent upon exposure to ovarian steroids prior to E1718 , a series of transplants using E15-16 fetuses as donors was made into intact or OVX-ADX hosts. In this case fetal sexes were not determined. As shown in Table I, again there was no difference in levels of cytosol estrogen receptors between transplants grown in the presence or absence of gonadal steroids. However, overall estrogen receptor levels were found to be significantly lower in 

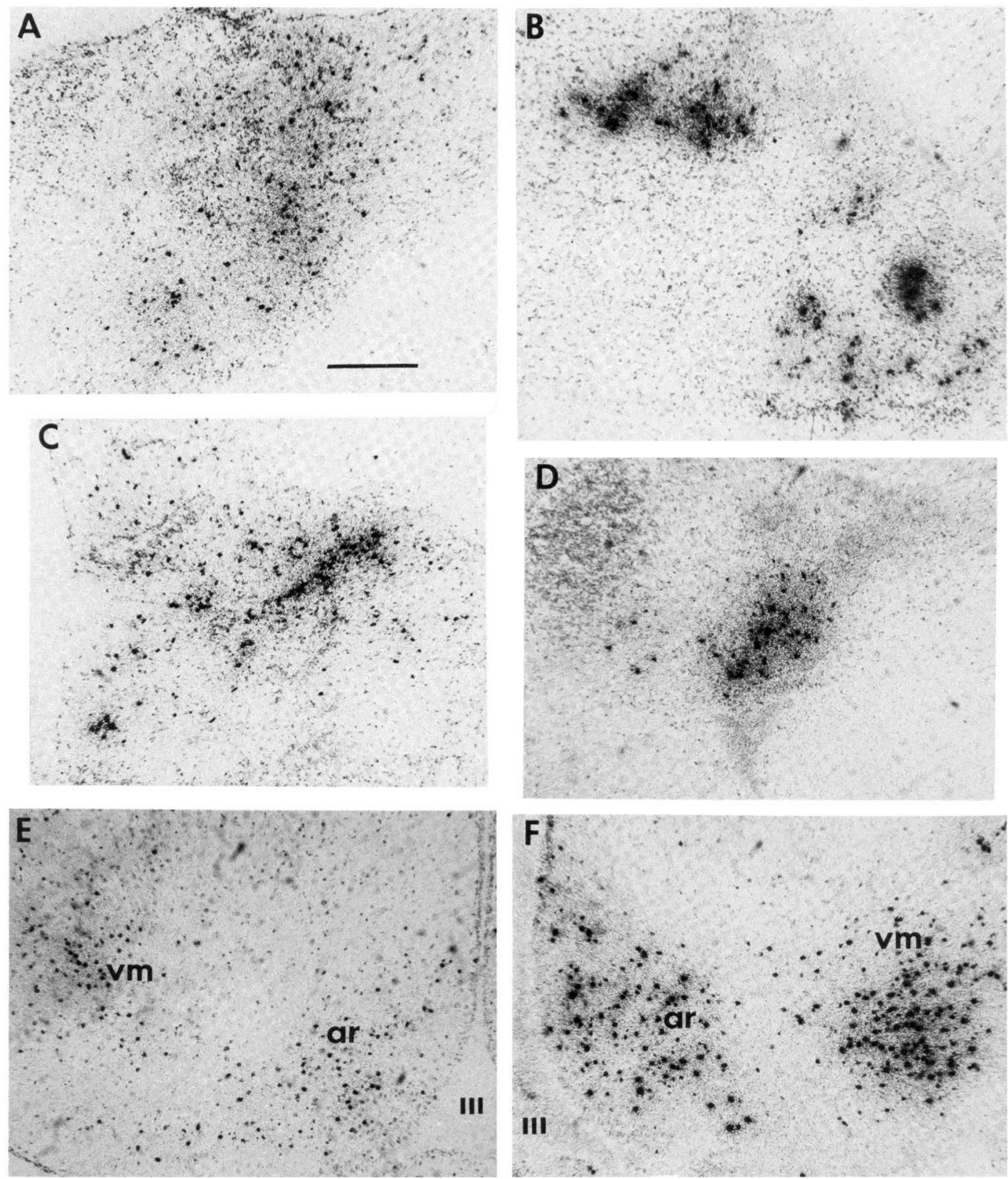

Figure 4. Autoradiograms of in vivo $\left[{ }^{3} \mathrm{H}\right]$ estradiol accumulation in E17-18 HPOA transplants and adult host hypothalamus from chronic OVX-ADX hosts. $A$ to $D$, Representative autoradiograms from four different HPOA transplants showing both scattered and clustered estrophilic cells, presumably neurons. Transplants were made onto the choroidal pia of OVX-ADX adult female hosts and [ $\left.{ }^{3} \mathrm{H}\right]$ estradiol autoradiography was performed 8 weeks later as described under "Materials and Methods." Estrophilic cells were observed in all transplants examined, and the range of densities of labeled cells appears comparable to that observed in the hypothalamus of the host animals (see below). In addition, there is no apparent difference in the density or overall pattern of labeling in transplants from OVX-ADX hosts versus those grown in gonadally intact hosts (see Fig. 5). $E$ and $F$, Autoradiograms of estrophilic cells in the arcuate (ar) and ventromedial $(\mathrm{vm})$ hypothalamic nuclei of 2 OVX-ADX host females showing the range from lightest $(E)$ to heaviest $(F)$ labeling observed in these experiments. III, third ventricle. All micrographs are to the same scale; bar $=200 \mu \mathrm{m}$. 

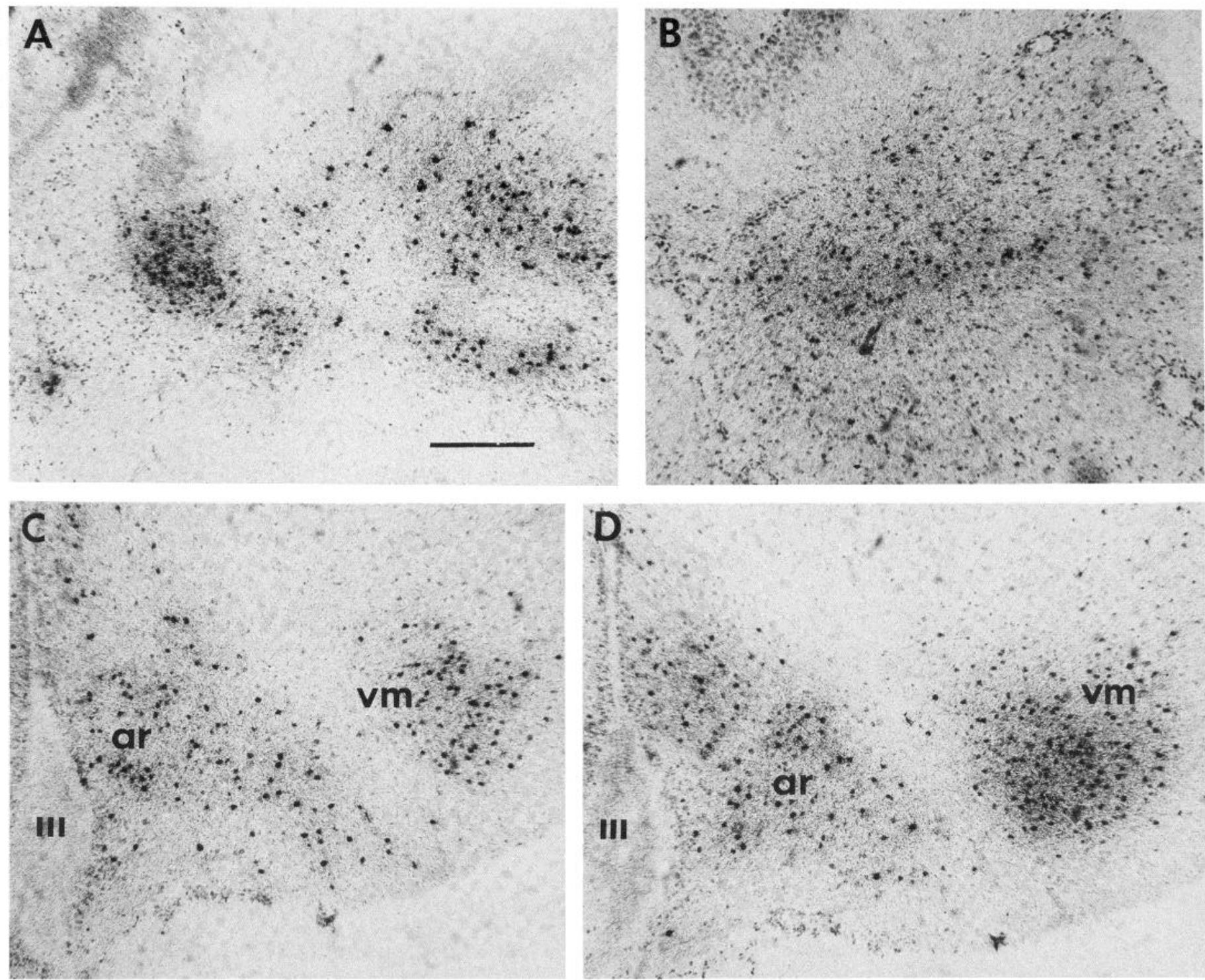

Figure 5. Autoradiograms of in vivo $\left[{ }^{3} \mathrm{H}\right]$ estradiol accumulation in E17-18 HPOA transplants and adult host hypothalamus from gonadally intact female hosts. $A$ and $B$, Representative autoradiograms from two different HPOA transplants showing both scattered and clustered estrophilic cells, presumably neurons. Transplants were made onto the choroidal pia of intact adult female hosts and $\left.{ }^{3} \mathrm{H}\right]$ estradiol autoradiography was performed 8 weeks later as described under "Materials and Methods" (hosts were ovariectomized $48 \mathrm{hr}$ before $\left[{ }^{3} \mathrm{H}\right]$ estradiol injection). Estrophilic cells were observed in all transplants examined, and the range of densities of labeled cells appears comparable to that observed in the hypothalamus of the host animals (see below). Similar findings in HPOA transplants from gonadally intact hosts were reported previously (Stenevi et al., 1980). $C$ and $D$, Representative autoradiograms showing estrophilic cells in the arcuate $(\mathrm{ar})$ and ventromedial $(\mathrm{vm})$ nuclei of two intact female hosts (ovariectomized $48 \mathrm{hr}$ before [ $\left.{ }^{3} \mathrm{H}\right]$ estradiol injection). III, third ventricle. All micrographs are to the same scale; $b a r=200 \mu \mathrm{m}$.

transplants from E15-16 fetuses than in those from E17-18 fetuses when expressed on a per milligram total cytosol protein basis (Table II). Transplants from E15-16 donors were generally larger than E1718 transplants, suggesting that the apparent difference in receptor levels might be due to a greater total protein level in the E15-16 cytosol pools. Therefore, estrogen receptor concentrations were recalculated on a per transplant basis. As shown in Table II, there is no difference between cytosol estrogen receptor levels from E1516 versus $\mathrm{E} 17-18$ fetuses when expressed in this manner.

In a few experiments fetal HPOA was transplanted into the anterior chamber of the eye of intact female hosts. Fetal ages ranged from $\mathrm{E} 17$ to E21, and tissue from both sexes was pooled. In all cases measurable levels of cytosol estrogen receptors were observed 8 weeks after transplantation. The mean cytosol estrogen receptor level $(6.03+1.82 \mathrm{fmol} / \mathrm{mg}$ of protein, $n=5)$ was not statistically different from that of E17-18 transplants grown on the choroidal pia (Table II; Student's $t=0.86, d f=30$, not significant).

\section{Characterization of cytosol estrogen receptors in transplanted HPOA}

Steroid specificity. Specificity of radiolabeled estradiol binding to transplant cytosol receptors was determined by adding a 300 -fold molar excess of unlabeled progesterone, corticosterone, testosterone, or estradiol to the incubation medium. As shown in Figure 2, only estradiol was effective in reducing binding, as is characteristic of authentic estrogen receptors.

Scatchard analysis. Equilibrium binding characteristics of transplant cytosol receptors were investigated by varying the concentration of $\left[{ }^{125} \mathrm{l}\right]$ estradiol in the incubation medium. Although the small amount of tissue available severely limited the number of points which could be determined, it was possible to sample four estradiol concentrations from 0.078 to $0.341 \mathrm{~nm}$. Figure 3 shows that the data could be fit reasonably well by linear regression $(r=-0.92)$, giving 


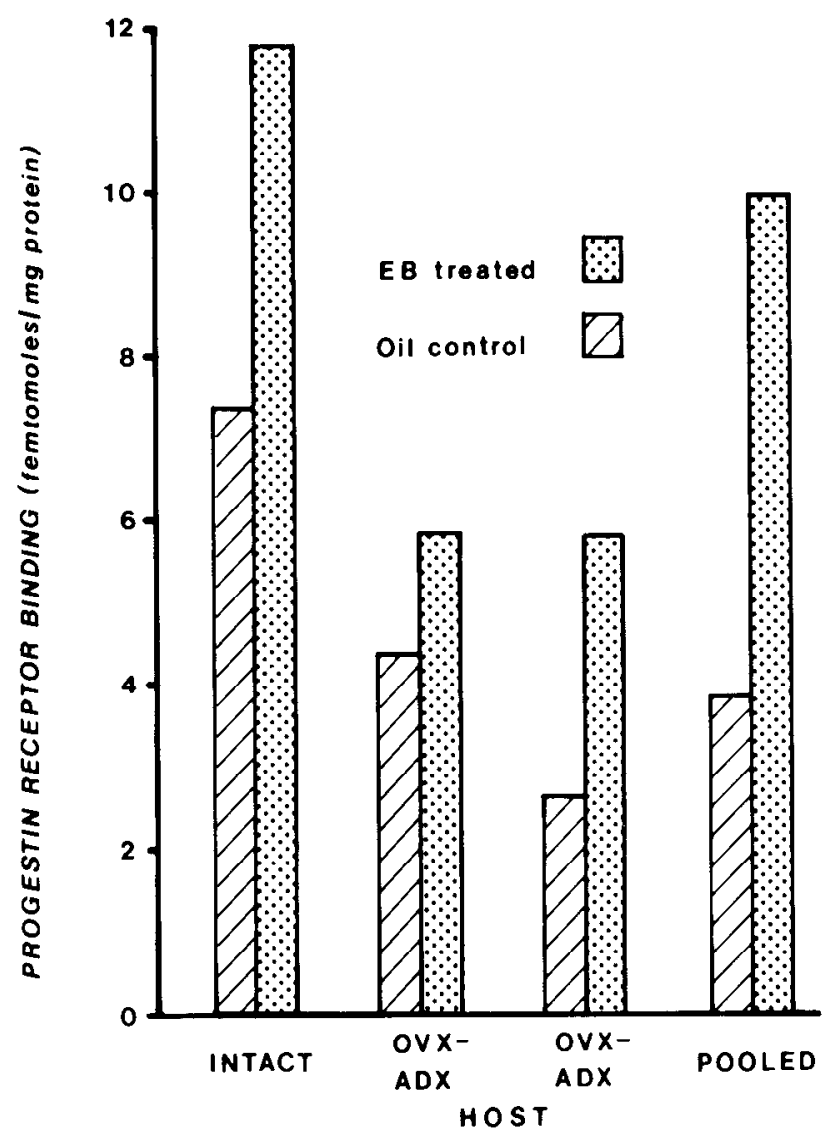

Figure 6. Estrogenic induction of cytosol progestin receptors in E17-18 HPOA transplants. Host animals received two injections of either $10 \mu \mathrm{g}$ of estradiol benzoate $(E B)$ or sesame oil vehicle (Oil control) 72 and $48 \mathrm{hr}$ before death, 8 weeks after transplantation. Transplants onto the choroidal pia were performed and progestin receptor binding was determined as described under "Materials and Methods." Shown are the results of four separate experiments using transplants grown in gonadally intact or ovariectomized-adrenalectomized (OVX-ADX) host females. In one case, transplants from both groups were pooled to obtain sufficient tissue for the assay. induction of progestin receptors by estradiol benzoate is apparent in each case, indicating that estrogen receptors are functionally mature in 8-week HPOA transplants whether or not the tissue has been previously exposed to gonadal steroids during development. The average induced level of progestin receptor binding is statistically greater than that of controls when data from all four experiments are pooled $(t=2.11, d f=6, p<0.05$; Student's $t$, onetailed).

an estimated equilibrium dissociation constant of $K_{d}=0.26 \mathrm{nM}$ and maximum binding of $B_{\max }=7.12 \mathrm{fmol} / \mathrm{mg}$ of cytosol protein.

\section{Autoradiography of estrophilic neurons in transplanted HPOA}

Neurons which contain estrogen receptors may be visualized autoradiographically because of their ability to sequester $\left[{ }^{3} \mathrm{H}\right]$ estradiol in vivo. Figures 4 and 5 show representative autoradiograms of E17-18 HPOA transplants and host hypothalamus from chronic OVX$\mathrm{ADX}$ and gonadally intact hosts, respectively, prepared following intravenous injection of $\left[{ }^{3} \mathrm{H}\right]$ estradiol. Estrophilic cells are present in transplants from both intact and OVX-ADX hosts, and there are no apparent differences in the general pattern of labeling of cells in transplants from the two groups. Although nuclear cell groups cannot be recognized within the transplants, labeled cells frequently occur in clusters similar to those found in the host arcuate and ventromedial nuclei (Figs. 4 and 5). It is reasonable to assume that these labeled cells are neurons. The neuronal nature of numerous estradiol-concentrating cells throughout the HPOA has been demonstrated by both retrograde tracing of their axonal projections and by immunocytochemical determination of their peptide content (Morrell et al.,
1984). Furthermore, in vivo concentration of $\left[{ }^{3} \mathrm{H}\right]$ estradiol by glial cells has not been reported.

\section{Estrogenic induction of progestin receptors in transplanted HPOA}

Induction of hypothalamic progestin receptors following estrogen treatment is first observed at 2 weeks of age in the rat (MacLusky and McEwen, 1980b), and this phenomenon has been shown to be mediated by estrogen receptors (Roy et al., 1979). In order to determine whether the estrogen receptor system in transplanted HPOA is sufficiently mature to exhibit this capability, host animals were given two injections of either $10 \mu \mathrm{g}$ of estradiol benzoate or sesame oil vehicle 72 and $48 \mathrm{hr}$ before death $(8$ weeks after transplantation). As shown in Figure 6 , induction of progestin receptors occurred in each of four experiments and was apparent in transplants from both intact and OVX-ADX hosts.

\section{Discussion}

These data are consistent with the conclusion that functional estrogen receptors develop in the HPOA independently of the steroid environment. Levels of cytosol receptors in mature HPOA transplants were not altered by growing the tissue under gonadal steroid-free conditions in OVX-ADX hosts from day 15 to 16 of gestation onward. Similarly, continuous exposure to estradiol for the first 4 weeks following transplantation did not affect receptor levels. These findings are consistent with previous studies where no change in limbic estrogen receptors was observed at postnatal day 22 following ovariectomy or testosterone treatment of 3-day-old neonates (MacLusky et al., 1979b), and with the report that neonatal ovariectomy failed to alter the maturation of uterine estrogen receptors (Clark and Gorski, 1970). The use of tetal transplantation has made it possible to extend the conclusions based on neonatal treatments to the prenatal steroid environment. Thus, it appears that the marked increase in levels of estrogen receptors in the HPOA following their initial detection between E15 and E21 (MacLusky et al., 1979a; Vito and Fox, 1982) occurs without significant modulation by gonadal steroids. However, our experiments provide no insights into the signals-hormonal or otherwise-which trigger the initial determination that certain neurons will express the steroid receptor phenotype.

The sex of the donor fetus was also found to have no apparent effect on cytosol estrogen receptor levels in the mature transplanted HPOA. This result is consistent with the demonstrated lack of sex differences in estrogen receptor concentrations in the hypothalamus of adult (Korach and Muldoon, 1974), neonatal (Westley and Salaman, 1977), and E21 fetal rals (MacLusky et al., 1979a) as well as the neonatal mouse (Fox, 1975). With respect to the lack of effect of both steroids and fetal sex, however, it should be noted that the present results do not preclude alterations in estrogen receptors localized to either single neurons or to small areas of the HPOA.

Estrogen receptors were also measurable in cytosol of transplants grown in the anterior chamber of the eye (Table II), and levels were comparable to those of transplants onto the choroidal pia. Thus, it does not appear that there are any factors specific to the transplantation site within the mature brain which are required for development of the embryonic estrophilic neurons. This result is consistent with reports of other investigators using both intraocular transplants (Nishizuka and Arai, 1982) and in vitro explant cultures (ToranAllerand et al., 1980) as discussed below.

The saturable binding of estradiol to transplanted HPOA cytosol protein exhibited the steroid specificity and high affinity characteristic of authentic estrogen receptors. In addition, the ability of estrogen treatment to induce progestin receptors in the transplanted HPOA indicates that these estrogen receptors are functionally mature (MacLusky et al., 1980b). The fact that induction was observed in transplants from both intact female and OVX-ADX hosts reveals that perinatal exposure to gonadal steroids is not required for the development of the estrogen-responsive mechanism of neural progestin receptor induction. 
To our knowledge, this increase in progestin receptors represents the first demonstration of an estrogenic effect in explanted brain tissue which represents induction of a specific protein. Furthermore, it is clear from the work of others that estrophilic neurons in brain explants may exhibit complex morphological responses to estrogens. In vitro organotypic cultures of newborn mouse HPOA respond to estrogen with a dramatic neuritic outgrowth (Toran-Allerand, 1976, 1980), and this response arises from areas of the explant containing estrophilic neurons (Toran-Allerand, 1980) and is blocked by treatment with the estrogen receptor antagonist Cl628 (Toran-Allerand, 1976). Transplants of medial amygdala from newborn rats grown in the anterior chamber of the eye demonstrated an increased density of synapses on dendritic shafts in response to estradiol (Nishizuka and Arai, 1982). Although knowledge of the molecular chain of events involved in these morphological changes is fragmentary, it is reasonable to assume that induction of specific proteins by estrogens is involved. The present demonstration that estrugens can induce progestin receptors in transplanted HPOA provides additional evidence that the cellular mechanisms by which estrogen alters protein synthesis are indeed operative in neural transplants. Taken together, all of these experiments support the view that studies of explarts of perinatal neuroendocrine tissue grown either in vitro, in oculo, or in the brain do provide data relevant to the normal mechanisms of steroid action in the CNS.

The fact that estrogen receptor development appears to be independent of either the perinatal steroid environment or the sex of the fetus supports the view that fetal testicular secretions act as a "trigger" which activates a pre-existing neural mechanism in order to induce sexual differentiation of the brain (Mc.Ewen, 1978). The present results do not support the suggestion of Döhler (1978) that embryonic exposure to estrogens might be necessary to induce or imprint undifferentiated steroid receptors into an estrophilic form. The recent failure to find a fetal sex difference in neural androgen aromatase levels (George and Ojeda, 1982; Weisz et al., 1982), as had previously been suggested to exist (Reddy et al., 1974), indicates that the ontogeny of this additional obligatory factor in sexual differentiation may also be independent of the tetal steroid environment. Future experiments on the development of aromatase in fetal HPOA transplants could be useful in further exploring this question. Based on the currently available evidence, then, the most parsimonious hypothesis is that the capacity for response to the testicular steroids which trigger sexual differentiation is inherent in the developing brain, regardless of the sex of the fetus.

\section{References}

Barraclough, C. A., and R. A. Gorski (1962) Studies on mating behavior in the androgen-sterilized female rat in relation to the hypothalamic regulation of sexual behavior. J. Endocrinol. 25: 175-182.

Beach, F. A. (1975) Hormonal modification of sexually dimorphic behavior. Psychoneuroendocrinology 1: 3-23.

Booth, J. E. (1977) Effects of the aromatization inhibitor, androst-4-ene$3,6,17$-trione on sexual differentiation induced by testostcrone in the neonatally castrated rat. J. Endocrinol. 72 : 53P-54P.

Bradford, M. M. (1976) A rapid and sensitive method for quantitation of micrograrn quartities of protein utilizing the principle of protein-dye binding. Anal. Biochem. 72: 248-254.

Chatelain, A., J. -P. Dupouy, and P. Allaume (1980) Fetal-maternal adrenocorticotropin and corticosterone relationships in the rat: Effects of maternal adrenalectomy. Endocrinology 106: 1297-1303.

Christensen. L. W., and R. A. Gorski (1978) independent masculinization of neuroendocrine systems by intracerebral implants of testosterone or estradiol in the neonatal female rat. Brain Res. 146: 325-340.

Clark, J. H., and R. A. Gorski (1970) Ontogeny of the cstrogen receptor during early uterine development. Science 169: 76-78.

Döhler, K. D. (1978) Is female sexual differentiation hormone-mediated? Trerids Neurosci. 1: 138-140.

Fox, T. O. (1975) Oestradiol receptor of neonatal mouse brain. Nature 258 : $441-444$.

George, F. W., and S. R. Ojeda (1982) Changes in aromatase activity in the rat brain during embryonic, neonatal and infantile development. Endocrinology 111: 522-529.

Korach, K. S., and T. G. Muldoon (1974) Studies on the nature of the hypothalamic estradiol-concentrating mechanism in the male and female rat. Endocrinology 94: 785-793.

Lieberburg, I., and B. S. McEwen (1975) Estradiol-17ß: A metabolite of testosterone recovered in cell nuclei from limbic areas of neonatal rat brains. Brain Res. 85: 165-170.

MacLusky, N. J., and B. S. McEwen (1980a) Progestin receptors in rat brain: Distribution and properties of cytoplasmic progestin-binding sites. Endocrinology 106: 192-202.

MacLusky, N. J. and B. S. McEwen (1980b) Progestin receptors in the developing rat brain and pituitary. Brain Res. 189: 262-268.

MacLusky, N. J., I. Lieberburg, and B. S. McEwen (1979a) The development of estrogen receptor systems in the rat brain: Perinatal development. Brain Res. 178: 129-142.

MacLusky, N. J., C. Chaptal, and B. S. McEwen (1979b) The development of estrogen receptor systems in the rat brain and pituitary: Postnatal development. Brain Res. 178: 143-160.

McEwen, B. S. (1978) Sexual maturation and differentiation: The role of the gonadal steroids. Prog. Brain Res. 48: 291-307.

McEwen, B. S., I. Lieberburg, C. Chaptal, and L. C. Krey (1977) Aromatization: Important for sexual differentiation of the neonatal rat brain. Horm. Behav. 9: 249-263.

McEwen, B. S., I. Lieberburg, C. Chaptal, P. G. Davis, L. C. Krey, N. J. MacLusky, and E. J. Roy (1979) Attenuating the defeminization of the neonatal ral brain: Mechianisirs of action of cyproterone acetate, 1,4,6androstatriene-3,17-dione and a synthetic progestin, R5020. Horm. Behav. 13: $269-281$.

Milkovic, K., J. Paunovic, Z. Kniewald, and S. Milkovic (1973) Maintenance of the plasma corticosterone concentration of adrenalectomized rat by the fetal adrenal glands. Endocrinology 93: 115-118.

Morrell, J. I. M. Schwanzel-Fukuda, S. E. Fahrbach, and D. W. Pfaff (1984) Axonal projections and peptide content of steroid hormone concentrating neurons. Peptides 5 (Suppl. 1): 227-239

Nishizuka, M., and Y. Arai (1982) Synapse formation in response to estrogen in the medial amygdala developing in the eye. Proc. Natl. Acad. Sci. U. S. A. 79: 7024-7026.

Olson, L., and T. Malmfors (1970) Growth characteristics of adrenergic nerves in the adult rat. Fluorescence histochemical and ${ }^{3} \mathrm{H}$-noradrenaline uptake studies using tissue transplantation to the anterior chamber of the eye. Acta Physiol. Scand. Suppl. 348: 1-112.

Plapinger, L., and B. S. McEwen (1978) Gonadal steroid-brain interactions in sexual differentiation. In Biological Determinants of Sexual Behavior, J. Hutchinson, ed., pp. 193-218, John Wiley \& Sons, Inc., New York.

Reddy, V. V. R., F. Naftolin, and K. J. Ryan (1974) Conversion of androstenedione to estrone by neural tissues from fetal and neonatal rats. Endocrinology 94: 117-121

Roy, E. J., N. J. MacLusky, and B. S. McEwen (1979) Antiestrogen inhibits the induction of progestin receptors by estradiol in the hypothalamus. preoptic area and pituitary. Endocrinology 104: 1333-1336.

Stenevi, U., A. Bjorklund, and N. -A. Svendgaard (1976) Transplantation of central and peripheral monoamine neurons to the adult rat brain: Techniques and conditions for survival. Brain Res. 114: 1-20.

Stenevi, U., A. Bjorklund, L. F. Kromer, C. M. Paden, J. L. Gerlach, B. S. McEwen, and A. -J. Silverman (1980) Differentiation of embryonic hypothalamic transplants cultured on the choroidal pia in brains of adult rats. Cell Tissue Res. 205: 217-228.

Toran-Allerand, C. D. (1976) Sex steroids and the development of the newborn mouse hypothalamus and preoptic area in vitro: Implications for sexual differentiation. Brain Res. 106: 407-412.

Toran-Allerand, C. D. (1980) Sex steroids and the development of the newborn mouse hypothalamus and preoptic area in vitro. II. Morphological correlates and hormonal specificity. Brain Res. 189: 413-427.

Toran-Allerand, C. D., J. L. Gerlach, and B. S. McEwen (1980) Autoradiographic localization of $\left[{ }^{3} \mathrm{H}\right]$ estradiol related to steroid responsiveness in cultures of the newborn mouse hypothalamus and preoptic area. Brain Rcs. 184: 517-522

Vito, C. C., and T. O. Fox (1982) Androgen and estrogen receptors in embryonic and neonatal rat brain. Dev. Brain Res. 2: 97-110.

Vreeburg, J. T. M., P. D. M. van der Vaart, and P. van der Schoot (1977) Prevention of central defeminization but not masculinization in male rats by inhibition neonatally of estrogen biosynthesis. J. Endocrinol. 74: 375382. 
Weisz, J., and C. Gibbs (1974) Metabolites of testosterone in the brain of the newborn female rat after an injcction of tritiated testosterone. Neuroendocrinology 14: 72-86.

Weisz, J., and I. L. Ward (1980) Plasma testosterone and progesterone titers of pregnant rats, their male and lemale leluses and neonatal offspring. Endocrinology 106: 306-316.
Weisz, J., B. L. Brown, and I. L. Ward (1982) Maternal stress decreases steroid aromatase activity in brains of male and female rat fetuses. Neuroendocrinology 35: 374-379.

Westley, B. R., and D. F. Salaman (1977) Nuclear binding of the oestrogen receptor of neonatal rat brain after injection of oestrogens and androgens; localization and sex differences. Brain Res. 119: 375-388. 